\title{
Lack of allelopathic effects of the domoic acid-producing marine diatom Pseudo-nitzschia multiseries
}

\author{
Nina Lundholm ${ }^{1, *}$, Per Juel Hansen ${ }^{1}$, Yuichi Kotaki ${ }^{2}$ \\ ${ }^{1}$ Marine Biological Laboratory, Strandpromenaden 5, 3000 Helsingør, Denmark \\ ${ }^{2}$ School of Fisheries Sciences, Kitasato University, Sanriku, Ofunato 022-0101, Japan
}

\begin{abstract}
Many Pseudo-nitzschia species produce the toxin domoic acid, which accumulates in the food web during blooms, sometimes causing amnesic shellfish poisoning (ASP) in higher trophic levels, including humans. In addition, Pseudo-nitzschia species have been reported to form longlasting monospecific blooms, and a possible explanation for this could be allelopathic effects of the toxin, since domoic acid has been detected in high amounts in the surrounding medium in stationary growth phase. We therefore examined the potential allelopathic effects of $P$. multiseries and its toxin domoic acid. In mixed-batch culture studies of domoic acid-producing $P$. multiseries and the algal test species Chrysochromulina ericina, Heterocapsa triquetra, Eutreptiella gymnastica and Rhodomonas marina, no allelopathic effects of $P$. multiseries were found. Different growth results using 2 different strains of $P$. multiseries grown with $C$. ericina were explained by minor differences in $\mathrm{pH}$. Bioassays testing the effect of domoic acid itself on 9 different phytoplankton species, namely $C$. ericina, E. gymnastica, Karenia mikimotoi, H. triquetra, Heterosigma akashiwo, Prorocentrum minimum, P. micans, Pyramimonas propulsa and R. marina confirmed a lack of allelopathic effects of the toxin. This lack of allelopathic effect of the shellfish-poisoning toxin domoic acid seems to correspond with the results of phytoplankton species causing DSP (diarrheic shellfish poisoning) and PSP (paralytic shellfish poisoning), where it appears that these shellfish-poisoning toxins do not cause allelopathic effects either.
\end{abstract}

KEY WORDS: Allelopathy $\cdot \mathrm{pH} \cdot$ Pseudo-nitzschia $\cdot$ Domoic acid $\cdot$ Diatom $\cdot$ Physiology $\cdot$ Ecology Inorganic carbon $\cdot$ Phytoplankton

\section{INTRODUCTION}

The availability of nutrients is considered one of the main factors controlling growth of phytoplankton, thus species that are successful in competition for growthlimiting nutrients will potentially become relatively more abundant than their competitors. Another factor influencing succession among phytoplankton is allelopathic interactions. Production of allelopathic substances inhibits growth of competitors and, hence, gives competitive advantages to the species producing the allelopathic substances (e.g. Cembella 2003, Gross 2003).

In marine phytoplankton, production of allelopathic substances is known from the prymnesiophytes, where the ichthyotoxic species Prymnesium parvum and Chrysochromulina polylepis have been shown to exhibit strong allelopathic effects on a number of other organisms (Myklestad et al. 1995, Schmidt \& Hansen 2001, Granéli \& Johansson 2003). Differences in sensitivity to allelopathic substances have been found among organisms, e.g. the effect of $P$. parvum filtrate on a natural plankton community varied among groups. The effect was greatest on diatoms and nanoflagellates, and smaller on dinoflagellates and cyanobacteria (Fistarol et al. 2003). Similarly, the allelopathic effect of C. polylepis differed among the 15 phytoplankton species tested; a growth depressing allelopathic effect was shown for 10 species. However, the 
dinoflagellate Prorocentrum minimum was not affected and in the case of 4 other species, a potential allopathic effect could not be differentiated from a potential inhibiting effect of elevated pH (Schmidt \& Hansen 2001).

The allelopathic effects of Chrysochromulina polylepis and Prymnesium parvum may contribute to the ability of the organisms to form monospecific blooms. $P$. parvum is known to form monospecific blooms (Granéli \& Johansson 2003) and a major bloom of $C$. polylepis in the pycnocline in Scandinavian waters in 1988 was observed to be almost monospecific $;$ no other autotrophic organisms or heterotrophic grazers were observed during the peak of the bloom. Only dying cells of the dinoflagellate Ceratium were detected (Dahl et al. 1989, Nielsen et al. 1990). Another ichthyotoxic organism, the dinoflagellate Karenia mikimotoi, is also known to exert allelopathic effects on a number of other phytoplankton organisms (Gentien \& Arzul 1990). The ecological significance of this is supported by field observations of a bloom of K. mikimotoi, where reduced algal growth of other organisms was found (Arzul et al. 1993); hence, the allelopathic effects of these ichthyotoxic organisms have been firmly established and may have ecological relevance. On the contrary, reports on allelopathic effects of the shellfishpoisoning toxins causing DSP (diarrheic shellfish poisoning), PSP (paralytic shellfish poisoning) and ASP (amnesic shellfish poisoning) are contradictory, and in the case of ASP, not thoroughly studied (Windust 1992, Subba Rao et al. 1995, Sugg \& Van Dolah 1999, Tillmann \& John 2002).

Marine diatoms of the genera Pseudo-nitzschia, Nitzschia and Amphora have been recognised as producers of domoic acid, the toxin responsible for ASP (e.g. Bates et al. 1989, Maranda et al. 1990, Lundholm et al. 1994, Kotaki et al. 2000). During blooms of toxinproducing diatoms, domoic acid may accumulate in the food web and an array of different organisms such as shellfish may serve as vectors for the toxin (e.g. McGinness et al. 1995, Bargu et al. 2002). Domoic acid may hereby cause harm to seabirds, mammals and humans (e.g. Bates et al. 1989, Work et al. 1993, Scholin et al. 2000). Hence, accumulation of domoic acid could have serious implications for human health, the environment and the economy (e.g. in small communities, which economically depend on shellfish fishery).

Pseudo-nitzschia species are regular components of phytoplankton all over the world (Hasle 2002); however, knowledge about the distribution and abundance of toxic Nitzschia species in nature is only just emerging (Kotaki et al. 2004). When blooming, Pseudonitzschia may form dense blooms, $10^{6}$ to $10^{8}$ cells $\mathrm{l}^{-1}$. The blooms are sometimes reported to be more or less monospecific, accounting for up to $99 \%$ of the total phytoplankton (e.g. Subba Rao et al. 1988, Martin et al. 1990, Walz et al. 1994, Dortch et al. 1997, Fryxell et al. 1997, Gallacher et al. 2001, Stonik et al. 2001). Apart from being monospecific, some of these blooms have been recorded to last for a long time. A monospecific bloom of $P$. multiseries in Cardigan Bay, Canada, in 1987 lasted for 2 mo (Bates et al. 1989).

The ecophysiological role of domoic acid has not yet been elucidated (Bates 1998, Cembella 2003). One of the hypotheses presented suggests that domoic acid could function as an allelopathic substance. This could result in a competitive advantage for Pseudo-nitzschia and, hence, explain the existence of monospecific blooms. It could also explain the long duration of blooms of Pseudo-nitzschia species (Bates et al. 1989, Martin et al. 1990). In culture experiments, domoic acid has been found to be leaking or actively transported into the surrounding medium/water (Maldonado et al. 2002) and the amount of domoic acid in the medium may account for up to $95 \%$ of the total amount of domoic acid (Bates et al. 1991, Maldonado et al. 2002). The high levels of domoic acid in the medium support the hypothesis that an allelopathic effect of domoic acid represents a potential explanation for an ecophysiological function of the toxin.

The allelopathy hypothesis for domoic acid has so far only been examined using diatoms as test species. No allelopathic effects have been found on the 2 diatoms Chaetoceros gracilis Schütt and Skeletonema costatum (Greville) (Brightwell) Sundström (Windust 1992); hence, any potential effect on phytoplankton organisms other than diatoms has never been examined. In addition, allelopathic effects may vary among test organisms as shown for Prymnesium parvum and Chrysochromulina polylepis (Schmidt \& Hansen 2001, Fistarol et al. 2003).

In culture experiments, the potential effect of elevated $\mathrm{pH}$ on growth must be taken into consideration (Schmidt \& Hansen 2001, Lundholm et al. 2004). During photosynthesis, phytoplankton takes up dissolved inorganic carbon (DIC) and this may cause an elevation of $\mathrm{pH}$. Elevated $\mathrm{pH}$ has, thus, been detected in laboratory experiments and in natural environments during algal blooms (e.g. Hinga 1992, 2002, Macedo et al. 2001, Schmidt \& Hansen 2001, Hansen 2002). An example of the importance of $\mathrm{pH}$ in allelopathic studies is that of Phaedactylum tricornutum, for which the claimed allelopathic effect was later shown to be due to a much higher $\mathrm{pH}$ tolerance of $P$. tricornutum than of the species it was supposed to affect (D'Elia et al. 1979, Sharp et al. 1979, Goldman et al. 1981, 1982).

The aim of the present study was to examine the potential allelopathic effect of diatoms producing domoic acid. We studied the potential allelopathic effects 
of 2 toxic strains of Pseudo-nitzschia multiseries on Chrysochromulina ericina in mixed-batch culture experiments. C. ericina was chosen as it has an upper $\mathrm{pH}$ limit for growth close to that for P. multiseries. In this way, we tried to avoid that elevated $\mathrm{pH}$ would limit growth of either P. multiseries or the test algae. Furthermore, we examined the allelopathic effect of 1 of the $P$. multiseries strains on 3 other test species, which have previously been affected by allelopathic substances (Schmidt \& Hansen 2001).

We also examined the potential allelopathic effect of pure domoic acid additions to cultures of 9 different phytoplankton species. The test species were selected in order to represent different algal classes and to represent species that occur in natural environments together with Pseudo-nitzschia multiseries.

\section{MATERIALS AND METHODS}

Algal species, clones and culture conditions. Two different strains of Pseudo-nitzschia multiseries (OKPm013-2 and CL-195) were used as representatives of toxin-producing diatoms. Nine clones of different marine phytoplankton species were included as testorganisms for possible allelopathic effects. Information on strain designation, isolation place and date, and source is given in Table 1. All strains were clonal and non-axenic, and grown in L1-medium (Guillard \& Hargraves 1993) based on autoclaved seawater with a salinity of 32 psu. Extra silicate was added to gain a concentration 3 times higher than originally prescribed for the L1-medium. The cultures were maintained at $15 \pm 1^{\circ} \mathrm{C}$ and 15 to $25 \mu \mathrm{mol}$ photons $\mathrm{m}^{-2} \mathrm{~s}^{-1}$ following a light:dark cycle of 16:8 h. Illumination was provided by cool fluorescent lamps and the irradiance measured using a Li-1000, Li-Cor sensor equipped with a Li-193SA spherical quantum probe.

Allelopathic studies using mixed-batch cultures of Pseudo-nitzschia multiseries and Chrysochromulina ericina, Heterocapsa triquetra, Eutreptiella gymnastica or Rhodomonas marina. Two different $P$. multiseries strains and the other 4 algal species were grown as monoclonal batch cultures in $260 \mathrm{ml}$ Nunclon polystyrene flasks ( $260 \mathrm{ml}$ medium) mounted on a plankton wheel (1 rpm) in order to keep the cells in suspension. P. multiseries (strain OKPm013-2) was grown together with either one of the cultures $C$. ericina, $H$. triquetra, E. gymnastica and $R$. marina in mixed-batch culture under similar conditions. In addition, $P$. multiseries (Strain CL-195) was grown in a mixture with C. ericina. The experiments with the monoclonal cultures and the mixed cultures of the respective $P$. multiseries strain were carried out simultaneously. The experiments were carried out at an irradiance of $100 \mu \mathrm{mol}$ photons $\mathrm{m}^{-2} \mathrm{~s}^{-1}$, to ensure that neither growth nor production of domoic acid was light-limited (Bates 1998), and at $15 \pm$ $1^{\circ} \mathrm{C}$. The experiments were carried out in triplicate flasks. Prior to all experiments; the strains were acclimated to the experimental conditions for at least $5 \mathrm{~d}$. Inoculates used for the experiments were taken from exponentially growing cultures and initial experimental concentrations were ca. 2000 cells ml$^{-1}$. The $\mathrm{pH}$ was adjusted to ca. 8.0 prior to the experiment by addition of $1 \mathrm{mM} \mathrm{HCl}$ and afterwards allowed to drift. $\mathrm{pH}$ was measured using a Sentron pH-meter (model ArgusX) equipped with a red line probe with a relative accuracy of $\pm 0.01 \%$. The $\mathrm{pH}$-meter was calibrated (2-point calibration) using Sentron buffers of pH 7.0 and 10.0. Cell concentration and $\mathrm{pH}$ were measured daily until stationary growth phase; thereafter less frequently (1 to $5 \mathrm{~d}$ intervals). In the experiments with $C$. ericina

Table 1. Information on strain designation, sampling place and time, and source of the strains. SCCAP: Scandinavian Culture Collection of Algae and Protozoa

\begin{tabular}{|lllll|}
\hline Strain & \multicolumn{2}{c}{ Species } & Sampling place and date & Source \\
\hline K0562 & Chrysochromulina ericina & Prymnesiophyceae & Kattegat, March 1995 & SCCAP \\
K-0333 & Eutreptiella gymnastica & Euglenophyceae & Kattegat, Denmark, 1988 & SCCAP \\
K-0481 & Heterocapsa triquetra & Dinophyceae & Øresund, Denmark, 1988 & SCCAP \\
K-0246 & Heterosigma akashiwo & Raphidophyceae & Unknown & SCCAP \\
K-0260 & Karenia mikimotoi & Dinophyceae & Oslofjord, Norway, 1977 & SCCAP \\
K-0335 & Prorocentrum micans & Dinophyceae & Kattegat, Denmark, 1989 & SCCAP \\
K-0295 & Prorocentrum minimum & Dinophyceae & Kattegat, Denmark, 1989 & SCCAP \\
CL-195 & Pseudo-nitzschia multiseries & Bacillariophyceae & Deadman's Harbour, Bay of & Stephen Bates \\
& & & Fundy, Canada, Oct 9, 2002 & Yuichi Kotaki \\
OKPm013-2 & Pseudo-nitzschia multiseries & Bacillariophyceae & Okkiray Bay, Iwate Prefecture, & Japan, Sep 20, 2001 \\
K-0005 & Pyramimonas propulsa & Prasinophyceae & Port Phillip Bay, Australia & SCCAP \\
K-0435 & Rhodomonas marina & Cryptophyceae & Kattegat, Denmark, 1990 & SCCAP \\
\hline
\end{tabular}


and the $2 P$. multiseries strains, samples for domoic acid concentration in whole culture and in the filtrate were taken 6 to 10 times during the experiments (30 d). Subsamples for cell counting $(5 \mathrm{ml})$ and toxin analyses $(2 \times 10 \mathrm{ml})$ were taken at approximately the same time every day, and the $\mathrm{pH}$ of the medium was measured. After subsampling, the flasks were refilled with L1medium of the same $\mathrm{pH}( \pm 0.05)$ as the respective flask. Samples for enumeration were fixed in Lugol's solution (final concentration $2 \%$ ) and counted in a Sedgewick rafter chamber. Each counting was based on approximately 400 cells, corresponding to a deviation of $\pm 10 \%$ using 95\% confidence limits (Utermöhl 1958). Maximum growth rates $(\mu)$ were calculated based on the algorithm $\mu=\ln \left(\mathrm{N}_{t_{2}} / \mathrm{N}_{t_{1}}\right) /\left(t_{2}-t_{1}\right)$, where $\mathrm{N}_{t_{2}}$ and $\mathrm{N}_{t_{1}}$ are the cells numbers at times $t_{2}$ and $t_{1}$. Three successive cell counts were used in the calculations. Dilutions due to subsampling were adjusted for in calculations of the growth rates. For each subsampling for toxin analyses, 2 samples of $10 \mathrm{ml}$ were taken. One of the samples was immediately frozen and used for determination of toxin content in the whole culture (cells and medium), while the other sample was filtered using a Nuclepore filter $(0.8 \mu \mathrm{m}, 25 \mathrm{~mm})$ and the $8 \mathrm{ml}$ filtrate stored at $-20^{\circ} \mathrm{C}$ until analysis.

Allelopathic studies of the effect of domoic acid on 9 different phytoplankton species. Nine clones of different phytoplankton species: Chrysochromulina ericina, Eutreptiella gymnastica, Karenia mikimotoi, Heterocapsa triquetra, Heterosigma akashiwo, Prorocentrum minimum, P. micans, Pyramimonas propulsa and Rhodomonas marina were used for the experiments. One set of triplicates of each culture was grown with an addition of $23 \mu \mathrm{g}$ of domoic acid (BioVectra) $\mathrm{ml}^{-1}$. A control set of triplicates of each culture was grown without domoic acid. The experiments were carried out in $25 \mathrm{ml}$ glass vials in volumes of $7.5 \mathrm{ml}$, with initial cell concentrations of 600 to 2000 cells ml$^{-1}$. Cultures were exposed to $100 \mu \mathrm{mol}$ photons $\mathrm{m}^{-2} \mathrm{~s}^{-1}$ and kept at $15^{\circ} \mathrm{C}$. The $\mathrm{pH}$ was adjusted to 8.0 prior to the experiment by addition of $1 \mathrm{mM} \mathrm{HCl}$. Subsamples $(0.5 \mathrm{ml})$, after $0 \mathrm{~h}, 4 \mathrm{~h}, 1 \mathrm{~d}, 2 \mathrm{~d}, 5 \mathrm{~d}$ and $9 \mathrm{~d}$, for cell counting were applied directly to a Sedgewick rafter chamber containing $10 \mu \mathrm{l}$ Lugol's solution and counted immediately. Counting and calculation of growth rates was carried out as outlined above. At the end of the experiment, $\mathrm{pH}$ was measured in all vials. In addition, $4 \mathrm{ml}$ of each toxin-containing vial and $4 \mathrm{ml}$ of 1 of the control triplicates was frozen for toxin analyses. Subsamples of the cultures used for inoculation were also tested for the presence of domoic acid.

To examine the extent of potential photo-degradation of domoic acid during the experiment, a set of triplicate glass vials with $20 \mathrm{ml}$ of medium and $20 \mu \mathrm{g}$ of domoic acid $\mathrm{ml}^{-1}$ was simultaneously set up under the same conditions. Subsamples for toxin analyses (2 ml) were taken at $0 \mathrm{~h}, 4 \mathrm{~h}, 1 \mathrm{~d}, 2 \mathrm{~d}, 5 \mathrm{~d}$ and $9 \mathrm{~d}$, simultaneously with those from Expt 2.

Toxin analyses. For Expt 1, the whole culture samples were thawed, sonicated under cool conditions (less than $\left.10^{\circ} \mathrm{C}\right)$ and centrifuged $(8000 \times g, 10 \mathrm{~min})$. The obtained supernatant and the filtrate were analysed for domoic acid concentration, applying a slightly modified method of Pocklington et al. (1990), in which a Develosil ODS-5 column $(4.6 \times 250 \mathrm{~mm}$, Nomura Chemical) and a mobile phase of $40 \%$ acetonitrile in phosphate buffer ( $\mathrm{pH}$ 2.5) were used. The detection limit was $0.3 \mathrm{ng} \mathrm{ml}^{-1}$.

Toxin content in the cellular fraction was calculated by subtracting the filtrate content from the content of whole culture (cells plus medium). The toxin content per cell was calculated by dividing the content in the cellular fraction by the cell number.

For Expt 2, the cell-free medium fraction of each sample was applied for domoic acid measurement. The samples were analysed using a slightly modified HPLC-UV method according to Quilliam et al. (1989), in which the same Develosil ODS-5 column as described in Expt 1 and a mobile phase of $10 \%$ acetonitrile in phosphate buffer $(\mathrm{pH} 2.5)$ were used. The detection limit was $0.1 \mu \mathrm{g} \mathrm{ml} \mathrm{m}^{-1}$.

\section{RESULTS}

\section{Allelopathic studies using mixed batch cultures of Pseudo-nitzschia multiseries and Chrysochromulina ericina, Heterocapsa triquetra, Eutreptiella gymnastica and Rhodomonas marina}

The growth of the Pseudo-nitzschia multiseries strains was similar when grown as monoclonal batch cultures and as mixed batch cultures (Fig. 1A, C, G,I). The cultures started exponential growth phase after around $1 \mathrm{~d}$ and entered stationary growth phase after 4 to $5 \mathrm{~d}$, after which cell numbers slowly declined. When the cultures entered stationary growth phase, the $\mathrm{pH}$ in the medium increased to 9.0 and 8.9 in OKPm013-2 and CL-195, respectively (Fig. 1B,D,H,J). pH remained at these levels for around $14 \mathrm{~d}$, whereafter it slowly decreased.

When grown as a monoclonal batch culture, Chrysochromulina ericina entered exponential growth phase after 2 to $3 \mathrm{~d}$ (Fig. 1E) and attained a maximum growth rate of $0.41 \mathrm{~d}^{-1}$. After around 17 to $22 \mathrm{~d}$, it entered stationary growth phase and simultaneously, the $\mathrm{pH}$ in the medium reached a maximum of around 9.0 (Fig. 1F).

The fate of Chrysochromulina ericina when grown in mixed cultures differed between the 2 Pseudo- 

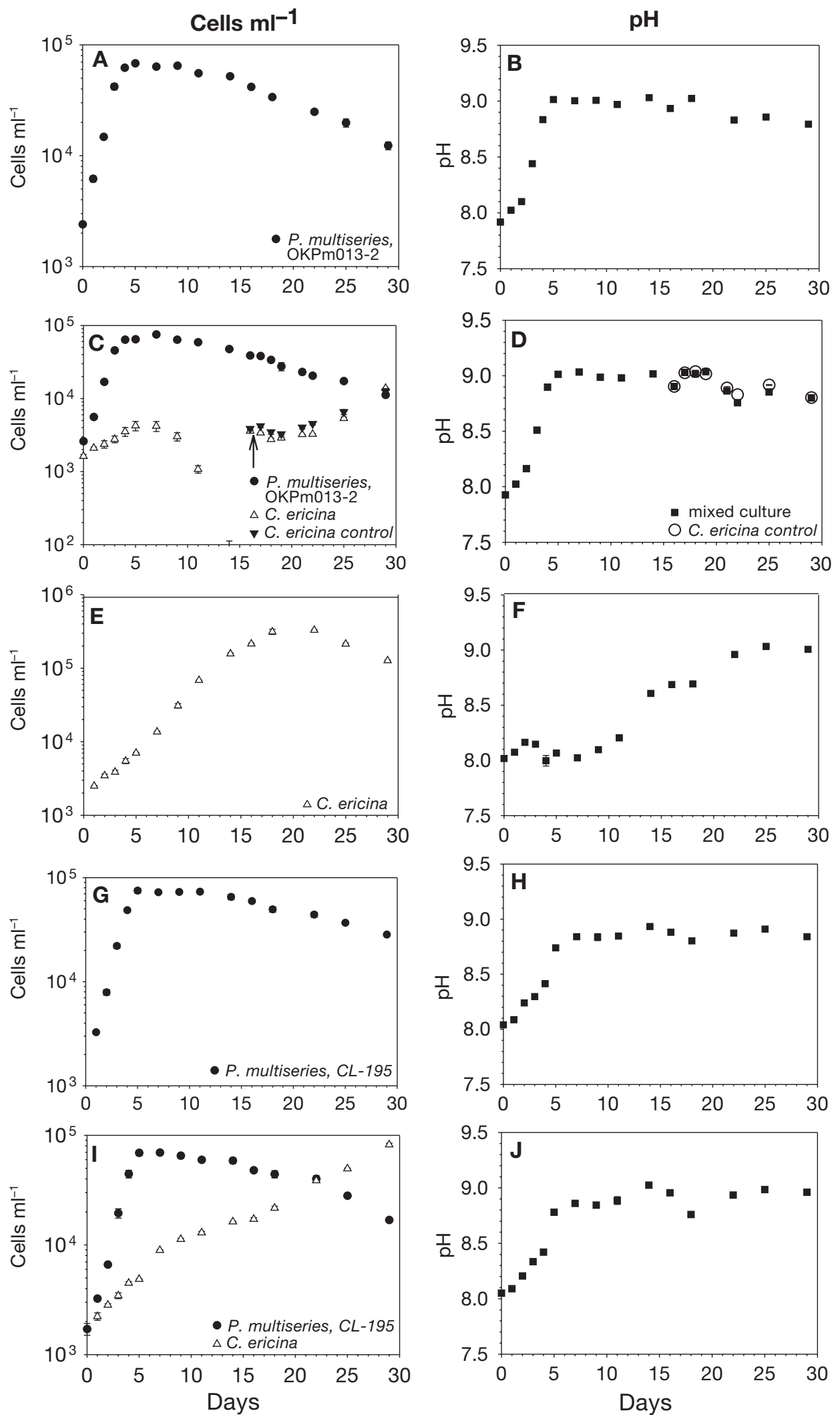

Fig. 1. Pseudo-nitzschia multiseries. Changes in cell numbers and $\mathrm{pH}$ as a function of time. (A-B) P. multiseries strain OKPm013-2. (C-D) Mixed-culture experiment with P. multiseries (CL-195) and Chrysochromulina ericina. Arrow indicates addition of new C. ericina cells. (E-F) C. ericina. (G-H) P. multiseries strain CL-195. (I-J) Mixed-culture experiment with P. multiseries (CL-195) and C. ericina. Data points refer to mean $\pm \mathrm{SE}, \mathrm{n}=3$ 
nitzschia multiseries clones. Mixed with OKPm013-2, C. ericina started exponential growth after 1 to $2 \mathrm{~d}$ and reached a maximum growth rate of $0.26 \mathrm{~d}^{-1}$ for $3 \mathrm{~d}$. Cell growth then stopped for $2 \mathrm{~d}$ and afterwards, cell numbers declined to 75 cells $\mathrm{ml}^{-1}$ (Fig. 1C). In order to test the reason for the decline in cell numbers of $C$. ericina, new cells of $C$. ericina were added to the flasks on Day 16, the concentration reaching 3000 cells $\mathrm{ml}^{-1}$. Simultaneously, triplicate control flasks with a similar number of $C$. ericina cells $\mathrm{ml}^{-1}$ in L-medium of the same $\mathrm{pH}$ were set up under the same conditions. The cell numbers remained more or less stable for $3 \mathrm{~d}$ (until Day 19) after which they started increasing and reached 10.00 cells $\mathrm{ml}^{-1} 9 \mathrm{~d}$ later, at the end of the experiment (Fig. 1C). The $\mathrm{pH}$ increased from 7.9 to 9.0 after $5 \mathrm{~d}$ and remained at this level for the next $14 \mathrm{~d}$ (until Day 19), after which it declined slightly (Fig. 1D).

In contrast to the experiment with OKPm013-2, Chrysochromulina ericina continued to grow throughout the experiment when mixed with CL-195 (Fig. 1I). C. ericina attained a maximum growth rate of $0.35 \mathrm{~d}^{-1}$; slower ( $t$-test: $\mathrm{p}<0.05)$ than in the monoclonal culture and cell numbers were never as high as in the monoclonal culture (Fig. 1I). pH increased to 8.8 after $5 \mathrm{~d}$ and remained at approximately 8.9 throughout the experiment (Fig. 1J).

In both mixed-culture experiments with Chrysochromulina ericina, domoic acid was detected in the medium after 10 to $15 \mathrm{~d}$ (around $1 \mathrm{wk}$ after entering stationary growth phase), and the concentrations increased for the remaining $15 \mathrm{~d}$ of the experiment (Fig. 2B,D). The concentrations attained were maximally 3 to $12 \mathrm{ng}$ domoic acid $\mathrm{ml}^{-1}$ in the medium (Fig. 2). Variations in the concentration of domoic acid detected in the medium were found between monoclonal cultures and mixed cultures; for CL-195, higher concentrations were found in the mixed cultures, whereas in OKPm013-2, the highest concentrations were found in the monoclonal cultures (Fig. 2). In all flasks, however, the amount of domoic acid per cell was more or less similar at $0.85 \pm 0.15 \mathrm{pg}$ domoic acid cell $^{-1}$ on Day 29 (data not shown).

In the experiments with the 3 other test species, Heterocapsa triquetra, Eutreptiella gymnastica and Rhodomonas marina, growth of Pseudo-nitzschia
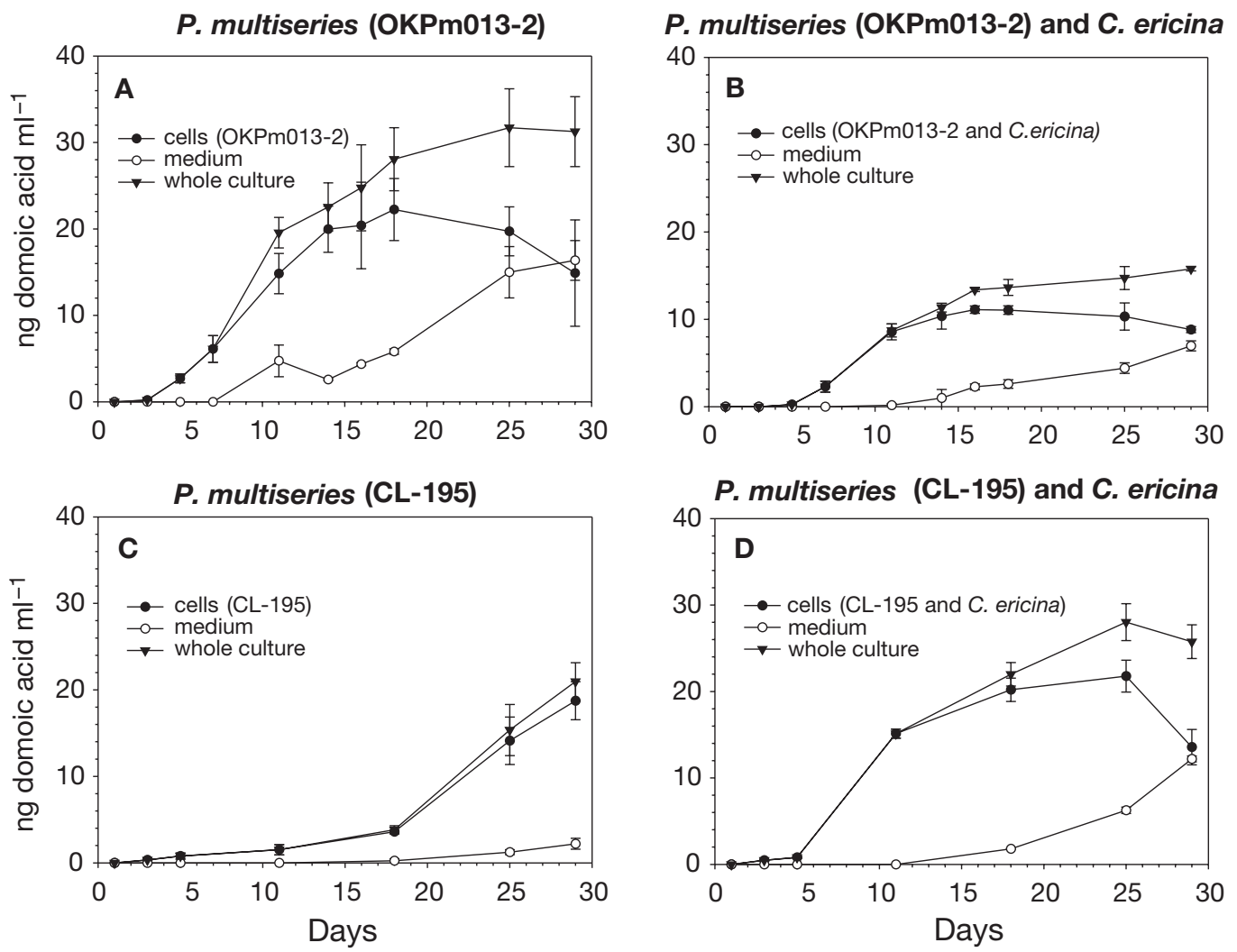

Fig. 2. Pseudo-nitzschia multiseries. Content of domoic acid in cell fraction $(\bullet)$, medium fraction (O) and in the whole culture $(\mathbf{\nabla})$ as a function of time in the monoclonal and mixed culture experiments. (A) P. multiseries (OKPm013-2). (B) Mixed culture experiment with P. multiseries (OKPm013-2) and Chrysochromulina ericina. (C) P. multiseries (CL-195). (D) Mixed culture experiment with P. multiseries (CL-195) and C. ericina. Data points refer to mean $\pm \mathrm{SE}, \mathrm{n}=3$ 
multiseries (OKPm013-2) was similar in all 3 mixed experiments until late stationary phase, at which time the cell numbers decreased with a different rate depending on the $\mathrm{pH}$ in the experiments. The highest rate of decrease was found in the experiment with $H$. triquetra, where $\mathrm{pH}$ reached the highest values (Fig. 3). The fate of the growth of the 3 test species showed similar trends (Fig. 3). Initially, the monocultures of the test species grew exponentially until Day 6 (H. triquetra and E. gymnastica) or Day 2 ( $R$. marina), and attained maximum growth rates of $0.51 \pm 0.02$, $1.02 \pm 0.03$ and $1.18 \pm 0.08 \mathrm{~d}^{-1}$ for $H$. triquetra, E. gymnastica and $R$. marina, respectively (Fig. 3A,C,E).
The cultures entered stationary growth phase and, more or less simultaneously, $\mathrm{pH}$ in the cultures reached a maximum of 9.35, 9.15 and 9.45, respectively (Fig. 3B,D,F).

In the mixed experiments, growth reached maximum growth rates of $0.47 \pm 0.05,1.02 \pm 0.05$ and 1.08 $\pm 0.4 \mathrm{~d}^{-1}$, respectively for Heterocapsa triquetra, Eutreptiella gymnastica and Rhodomonas marina for the first 2 to $4 \mathrm{~d}$; thereafter, the cultures grew with a lower rate than in the corresponding monocultures (Fig. 3A, C,E). In the mixed experiments, $\mathrm{pH}$ increased to values around 9 after 5 to $6 \mathrm{~d}$ and only increased or decreased slightly afterwards (Fig. 3B,D,F).
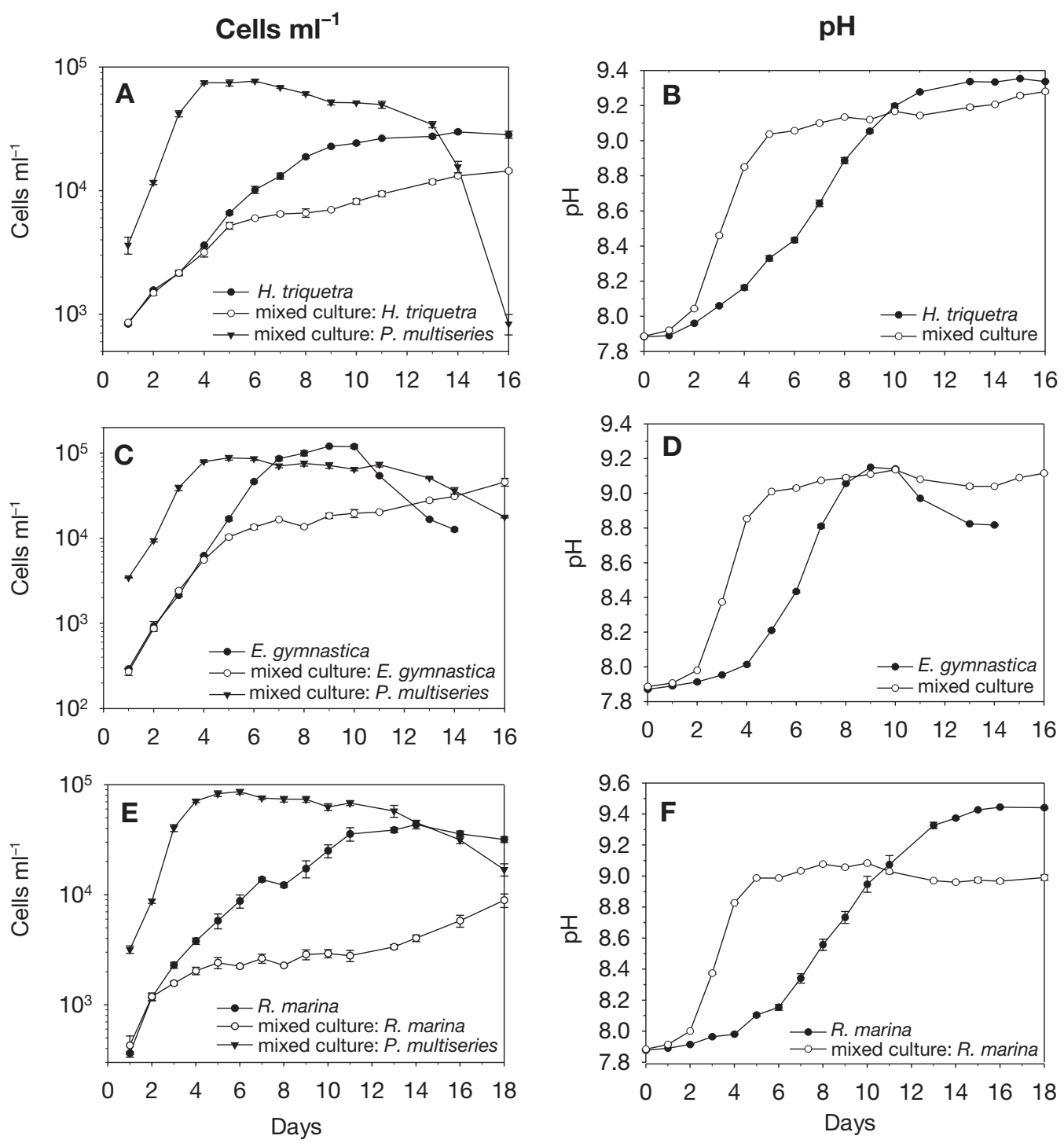

Fig. 3. Heterocapsa triquetra, Eutreptiella gymnastica and Rhodomonas marina. Changes in cell number and pH as a function of time. (A-B) Monoculture and mixed-culture experiment with Heterocapsa triquetra. (C-D) Monoculture and mixed-culture experiment with Eutreptiella gymnastica. (E-F) Monoculture and mixed-culture experiment with Rhodomonas marina. Data points refer to mean $\pm \mathrm{SE}, \mathrm{n}=3$ 

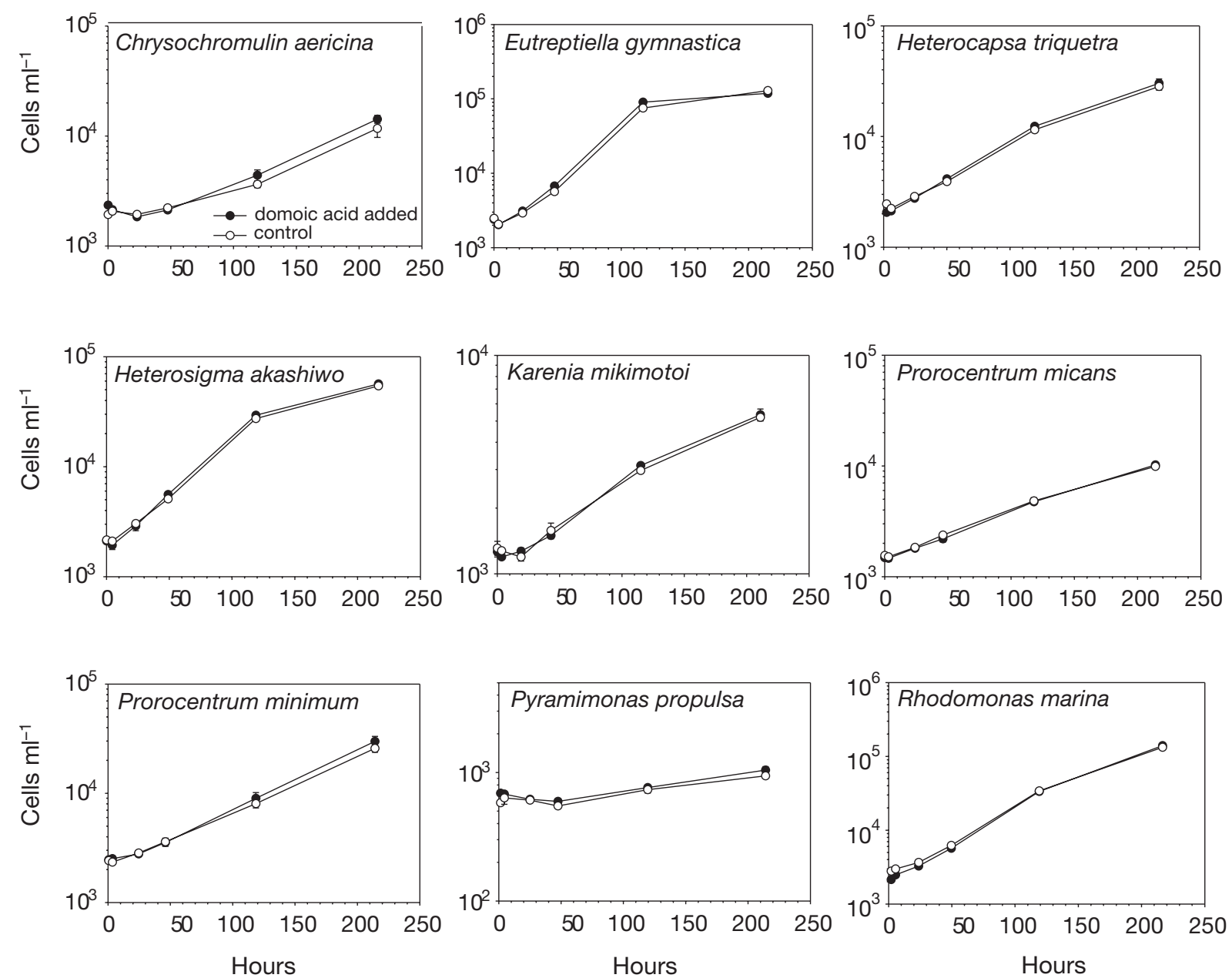

Fig. 4. Chrysochromulina ericina, Eutreptiella gymnastica, Heterocapsa triquetra, Heterosigma akashiwo, Karenia mikimotoi, Prorocentrum micans, P. minimum, Pyramimonas propulsa and Rhodomonas marina. Growth changes as a function of time in batch culture experiments with and without domoic acid. Data points refer to mean $\pm S E, n=3$

\section{Allelopathic studies of the effect of domoic acid on 9 different phytoplankton species}

The growth of all 9 phytoplankton test species did not differ between vials to which domoic acid had been added and vials without domoic acid (Fig. 4). The exponential growth rates of the test flasks with domoic acid and the control flasks were similar ( $t$-test: $\mathrm{p}>0.05)$. The $\mathrm{pH}$ values measured at the end of the experiment were not significantly different ( $t$-test: $\mathrm{p}>0.01$ ) in the flasks with domoic acid and in the control flasks. Toxin analyses of the cultures at the end of the experiment showed that the amounts of domoic acid detected at the end of the experiment was not significantly different ( $t$-test: $p>0.1$ ) from the amount detected in the vials with sterile medium (Fig. 5). No domoic acid was detected in the cultures used for inoculation of the test species or in the control flasks. In all flasks, the concentrations of domoic acid were above $20 \mu \mathrm{g}$ domoic acid $\mathrm{ml}^{-1}$ (mean $\pm \mathrm{SE}$ equals $23.0 \pm 0.2 \mu \mathrm{g}$ domoic acid $\mathrm{ml}^{-1}$ ).

The vials with domoic acid added to sterile Lmedium showed that the initial concentration of domoic acid (ca. $23.1 \pm 0.4 \mu \mathrm{g}$ domoic acid $\mathrm{ml}^{-1}$ ) decreased slightly during the experiment. A linear regression showed that the domoic acid concentration decreased to $22.6 \pm 0.4 \mu \mathrm{g}$ domoic acid $\mathrm{ml}^{-1}$ after $9 \mathrm{~d}$, corresponding to a decrease of $0.2 \%$.

\section{DISCUSSION}

\section{Allelopathic effects of 2 strains of Pseudo-nitzschia multiseries on Chrysochromulina ericina}

In the mixed-culture experiments, the fate of the test species Chrysochromulina ericina differed between 


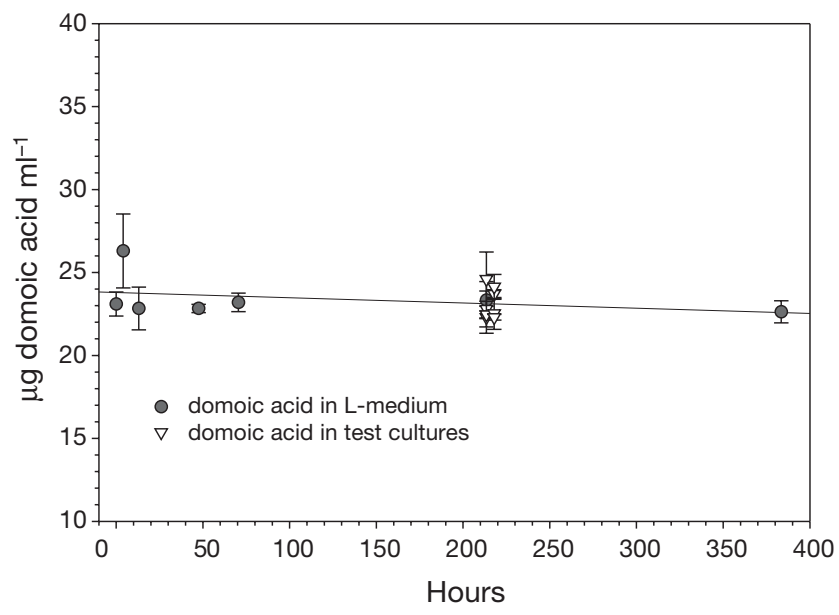

Fig. 5. Domoic acid content in sterile L-medium as a function of time (०) and domoic acid concentration at the end of the experiment of the test species in Expt $2(\nabla)$. Data points refer to mean $\pm \mathrm{SE}, \mathrm{n}=3$

the experiments with the 2 different Pseudo-nitzschia multiseries strains. In the experiment with $P$. multiseries strain OKPm013-2, the cell numbers of $C$. ericina declined $3 \mathrm{~d}$ after $P$. multiseries entered stationary growth phase. This could potentially look like an allelopathic effect of $P$. multiseries on $C$. ericina, as the production of domoic acid is known to begin in the stationary growth phase; however, the amount of domoic acid in the medium was close to the detection limit at the time when cell numbers of $C$. ericina declined. When the growth of $C$. ericina stopped and a few days later declined, $\mathrm{pH}$ values simultaneously reached the upper $\mathrm{pH}$ limit for growth of $C$. ericina ( $\mathrm{pH} \sim 9$ ). The upper $\mathrm{pH}$ limit for growth of $C$. ericina can be deduced from the monoclonal culture experiment, where $C$. ericina entered stationary growth phase when $\mathrm{pH}$ reached a value of $\sim 9$. It has previously been shown that in L- or f/2-medium, growth of $P$. multiseries and C. ericina is inhibited by elevated $\mathrm{pH}$ and not by nutrient limitation (Hansen \& Hjorth 2002, Lundholm et al. 2004). The $\mathrm{pH}$ value that indicates initiation of stationary growth phase must, therefore, be considered to be the upper $\mathrm{pH}$ limit for growth.

In order to ensure that it was elevated $\mathrm{pH}$ and not allelopathic substances that caused the decline in cell numbers in the mixed-culture experiment, more Chrysochromulina ericina cells were added on Day 16 ( $\mathrm{pH}$ value $~ 9$ ). The cell number of $C$. ericina began to increase on Day 20, when $\mathrm{pH}$ values declined to around $\mathrm{pH}$ 8.8. At the time when the added cells of $C$. ericina began to grow (Day 20), the concentration of domoic acid in the medium had increased to between 1 and $2 \mathrm{ng} \mathrm{ml}^{-1}$, and in the remaining part of the experiment, $C$. ericina was growing in spite of an increasing concentration of domoic acid, reaching levels of ca. $3 \mathrm{ng} \mathrm{ml}^{-1}$. During this part of the experiment, $\mathrm{pH}$ levels were $\sim 8.8$. This strongly indicates that the decline in cell numbers was an effect of elevated $\mathrm{pH}$ and not inhibition due to the presence of domoic acid or any other allelopathic substance produced by Pseudo-nitzschia multiseries.

This conclusion is supported by the mixed-culture experiment with the other Pseudo-nitzschia multiseries strain (CL-195) that has an upper $\mathrm{pH}$ limit for growth slightly lower than OKPm013-2. In this experiment, growth of Chrysochromulina ericina was high for the first $5 \mathrm{~d}$, during which $\mathrm{pH}$ values were increasing from 8.0 to between 8.8 and 8.9. During the remaining part of the experiment, the $\mathrm{pH}$ values stayed at this level and growth of $C$. ericina continued, but at a lower growth rate, due to the elevated $\mathrm{pH}$. The growth of $C$. ericina was not inhibited, but only reduced, as $\mathrm{pH}$ did not reach the upper $\mathrm{pH}$ limit for growth of $C$. ericina. The concentration of domoic acid in the medium was higher than in the experiment with OKPm013-2 (Fig. 2B,D); thus, the results of the 2 mixed-culture experiments show that, at the domoic acid concentration levels obtained, P. multiseries has no allelopathic effect on $C$. ericina. The experiments also show that no allelopathic effects of $P$. multiseries due to substances other than domoic acid were found.

\section{Allelopathic effects of Pseudo-nitzschia multiseries on Heterocapsa triquetra, Eutreptiella gymnastica and Rhodomonas marina}

In the experiments with Heterocapsa triquetra, Eutreptiella gymnastica and Rhodomonas marina, the fate of the 3 test algal species grown mixed with Pseudo-nitzschia multiseries was very similar. Initially, when $\mathrm{pH}$ values were low, growth in the mixed experiments was similar to that in the monocultures. In the monocultures, maximum growth rates were found until $\mathrm{pH}$ reached values of 8.4 (H. triquetra and $E$. gymnastica) and 8.2 (R. marina). As previously shown, (Lundholm et al. 2004), growth in L-medium is not nutrient-limited; hence, these $\mathrm{pH}$ values indicate the $\mathrm{pH}$ at which growth of the species becomes limited by elevated $\mathrm{pH}$ (Fig. 3B,D,F). When $\mathrm{pH}$ in the mixed experiments after 2 to $4 \mathrm{~d}$ reached the abovementioned values, growth was thereafter limited by elevated $\mathrm{pH}$ and slower compared to the corresponding monocultures. In the mixed experiments, $\mathrm{pH}$ reached values of around 9 after 5 to $6 \mathrm{~d}$ and growth of the 3 test species was, hence, limited by $\mathrm{pH}$ and attained growth rates of $0.08,0.10$ and 0.16 for $H$. triquetra, E. gymnastica and $R$. marina, respectively. When the monocultures reached similar $\mathrm{pH}$ values 
(Days 9, 10 and 11), the growth rates were not significantly different from the growth rates of the test species in the mixed cultures at similar $\mathrm{pH}$ (t-test: $\mathrm{p}>0.1$ ).

The results, hence, clearly show that the limited growth of the test species in the mixed experiments was due to high $\mathrm{pH}$ and not caused by allelopathic substances produced by Pseudo-nitzschia multiseries.

\section{Allelopathic effects of domoic acid}

Domoic acid was added to the test cultures at a concentration $>20 \mu \mathrm{g} \mathrm{ml}^{-1}$; a concentration clearly higher than what would be expected in the field. We tried to calculate the maximum amount of domoic acid that one could potentially find in the field. These calculations were based on the maximum amount of domoic acid detected in the medium in laboratory experiments $\left(3.2 \mu \mathrm{g}\right.$ domoic acid $\left.\mathrm{ml}^{-1}\right)$ at a Pseudo-nitzschia multiseries cell concentration of $18 \times 10^{7}$ cells $^{-1}$ (Bates et al. 1991). When relating the domoic acid concentration to the maximum cell numbers of $P$. multiseries detected in the field $\left(1.5 \times 10^{7}\right.$ cells l$\left.^{-1}\right)$ in a bloom in the Cardigan area in 1987 (Bates et al. 1989), maximum levels of domoic acid of around $0.3 \mu \mathrm{g} \mathrm{ml}^{-1}$ could be expected in water in the field. The amount of domoic acid added in the experiments was more than 60 times higher and should have elicited an allelopathic effect if allelopathic effects of domoic acid were to have an ecological significance.

No significant degradation of domoic acid took place during the experiment in which pure domoic acid was added to sterile L-medium (Fig. 5).

In the experiments with addition of pure domoic acid, the growth rates of the 9 different phytoplankton species in flasks with and without domoic acid were similar (Fig. 4). This shows that no allelopathic effect of domoic acid was found on Chrysochromulina ericina, Eutreptiella gymnastica, Karenia mikimotoi, Heterocapsa triquetra, Heterosigma akashiwo, Prorocentrum minimum, P. micans and Rhodomonas marina, indicating that no allelopathic effects of domoic acid are to be expected in the field. The experiment with Pyramimonas propulsa did not show any allelopathic effect either, but the cells grew very slowly (growth rate: $0.08 \mathrm{~d}^{-1}$ ) and maximally reached cell numbers of 1000 cells ml ${ }^{-1}$. The culture did not attain exponential growth and we can, therefore, only conclude that no acute allelopathic effects of domoic acid were detected.

Similar to our results, Windust (1992) did not detect allelopathic effects on the diatoms Chaetoceros gracilis and Skeletonema costatum in a bioassay using domoic acid in concentrations from $50 \mathrm{ng} \mathrm{ml}^{-1}$ to $50 \mu \mathrm{g} \mathrm{ml}^{-1}$. A study of allelopathic effects of Pseudo-nitzschia multi- series on Proboscia alata using mixed batch cultures claimed to show allelopathic effects of $P$. multiseries (Subba Rao et al. 1995); however, as the concentrations of domoic acid were never quantified, and the potential inhibiting effect of elevated $\mathrm{pH}$ not considered, drawing conclusions on allelopathic effects would be premature. The results in the present paper show how difficult it is to differentiate allelopathic effects from inhibition due to elevated $\mathrm{pH}$, and only a few studies have taken the inhibiting effect of elevated $\mathrm{pH}$ into account (Goldman et al. 1981, 1982, Schmidt \& Hansen 2001).

As no allelopathic effect of domoic acid was found, monospecific blooms of Pseudo-nitzschia observed in the field must be explained by factors other than allelopathic effects of domoic acid. In addition, no allelopathic effects of $P$. multiseries due to substances other than domoic acid were found in the mixed-culture experiments with Chrysochromulina ericina, Heterocapsa triquetra, Eutreptiella gymnastica or Rhodomonas marina; hence, we do not consider allelopathic effects of Pseudo-nitzschia species a likely explanation for formation of monospecific blooms of Pseudonitzschia.

\section{Allelopathic effects of shellfish toxins}

The fact that no allelopathic effects of the shellfishpoisoning phycotoxin, domoic acid, were found poses the question: What about the other shellfish-poisoning toxins that also cause effects on organisms at higher trophic levels? Is it a general phenomenon that the toxic effect of shellfish toxins seems to be of no significance for an allelopathic function of the toxin for the organism producing the toxin? Apart from ASP, shellfish toxins associated with DSP, PSP, NSP (neurotoxic shellfish poisoning), and AZP (azaspiracid shellfish poisoning) are known (Landsberg 2002).

DSP is caused by ocadaic acid and dinophysistoxins (DTX-1), potent phosphatase inhibitors produced by marine dinoflagellates of the genera Dinophysis and Prorocentrum (Dickey et al. 1990, Cembella 2003). In laboratory experiments, ocadaic acid and DTX-1 have been found to inhibit growth of 6 non-DSP-producing organisms (Uchida 1977, Windust et al. 1996). In addition, ocadaic acid has been found to be released to the surrounding water (Rausch de Trauenberg \& Morlaix 1995) and could, hence, potentially cause allelopathic effects. The toxin concentrations causing the growth inhibition are, however, much higher $(>0.5 \mu \mathrm{M}$ toxin; Windust et al. 1996) than the concentrations maximally observed in culture medium $\left(\sim 0.005\right.$ to $0.01 \mu \mathrm{M}_{\text {; }}$ Rausch de Trauenberg \& Morlaix 1995, Sugg \& Van Dolah 1999). In addition, Sugg \& Van Dolah (1999) 
showed that the growth-inhibiting factor eluted in a different fraction than ocadaic acid when Prorocentrum lima-conditioned medium was fractionated by HPLC (Sugg \& Van Dolah 1999). Sugg \& Van Dolah (1999), therefore, concluded that the growth-inhibiting effect on phytoplankton was mainly due to a substance other than ocadaic acid and its precursors. In addition, they stated that the growth-inhibiting substance was not in the ocadaic acid toxin family, as the growth-inhibitory and the protein-phosphatase-inhibitory activity did not co-elute. They did not, however, reject the possibility that ocadaic acid could function as a deterrent of some sort, e.g. a grazing deterrent (Sugg \& Van Dolah 1999); hence, the hypothesis that ocadaic acid could act as an allelopathic substance has been difficult to prove.

PSP is caused by saxitoxins and their derivatives, which are produced by a number of dinoflagellates such as Alexandrium and Pyrodinium. An allelopathic effect of Alexandrium species was shown by Blanco \& Campos (1988), who found that the PSP-producing A. lusitanicum reduced growth of other phytoplankton species, whereas the non-PSP-producing A. tamarense did not. They, therefore, suggested that the PSP toxins caused the allelopathic effect. Since then, the studies of allelopathic effects of Alexandrium species have been contradictory. Other studies have found that the allelopathic effect varied among strains of Alexandrium and did not always correlate with production of PSP-toxins (Arzul et al. 1999, Tillmann \& John 2002), indicating that PSP toxins have no allelopathic effect. In addition, the allelopathic effects have been shown to be due to the production of extracellular substances, which have yet to be identified (Arzul et al. 1999, Tillmann \& John 2002). A lack of allelopathic effects of the PSP-toxins probably also explains a similar discrepancy in effects of Alexandrium on other organisms such as grazing protists and copepods (Huntley et al. 1986, Hansen 1989, Turriff et al. 1995, Bagøien et al. 1996, Teegarden \& Cembella 1996, Dutz 1998, Teegarden 1999, see Tillmann \& John 2002).

The brevetoxins causing NSP are produced by, for example, the dinoflagellate Karenia brevis. $K$. brevis has been reported to cause allelopathic effects on phytoplankton species (Freeberg et al. 1979), but what actually caused the growth inhibition is unclear. No studies on potential allelopathic effects of the azaspirazids causing AZP have to our knowledge been conducted.

To conclude, a picture is emerging showing that the shellfish toxins responsible for at least DSP, PSP and ASP do not apparently cause direct allelopathic effects. In other words, the toxic effect on the higher trophic levels seems not to be related to toxic effects on competing organisms; thus, the allelopathic effects by DSP- and PSP-producing organisms seem to be caused by substances other than the shellfish toxins. Further research is needed to establish the source of the allelopathic effects, which are caused by some of these organisms.

\section{CONCLUSION}

No allelopathic effects due to the shellfish poisoning toxin, domoic acid, were found on a diverse array of autotrophic phytoplankton organisms. In addition, the lack of allelopathic effects of substances other than domoic acid indicate that Pseudo-nitzschia do not exert allelopathic effects. The lack of allelopathic effects of the shellfish-poisoning toxin which causes ASP is similar to DSP and PSP, where the shellfish toxins apparently do not cause allelopathic effects either. In fact, the allelopathic effects caused by DSP- and PSP-producing organisms seem to be attributable to other substances.

Acknowledgements. We would like to thank Stephen Bates for donation of a Pseudo-nitzschia multiseries culture and SCCAP for donations of several cultures. The work was funded by a grant to N.L. by the Carlsberg Foundation (grant 0656/20 and the Danish National Research Council project no. 21-03-0449 to P.J.H.).

\section{LITERATURE CITED}

Arzul G, Erard-Le Denn E, Videau C, Jegou AM, Gentien P (1993) Diatom growth repressing factors during an offshore bloom of Gyrodinium cf. aureolum. In: Smayda TJ, Shimizu Y (eds) Toxic phytoplankton blooms in the sea. Elsevier Sci Publ BV, Amsterdam, p 719-724

Arzul G, Seguel M, Guzman L, Erard-Le Denn E (1999) Comparison of allelopathic properties in three toxic Alexandrium species. J Exp Mar Biol Ecol 232:285-295

Bagøien E, Miranda A, Reguera B, France JM (1996) Effects of two paralytic shellfish toxin producing dinoflagellates on the pelagic harpacticoid copepod Euterpina acutifrons. Mar Biol 126:361-369

Bargu S, Powell CL, Coale SL, Busman M, Doucette GJ, Silver MW (2002) Krill: a potential vector for domoic acid in marine food webs. Mar Ecol Prog Ser 237:209-216

Bates SS (1998) Ecophysiology and metabolism of ASP toxin production. In: Anderson DM, Cembella AD, and Hallegraeff GM (eds) Physiological ecology of harmful algal blooms. Springer-Verlag, Heidelberg, p 405-426

Bates SS, Bird CJ, de Freitas ASW, Foxall R and 13 others (1989) Pennate diatom Nitzschia pungens as the primary source of domoic acid, a toxin in shellfish from eastern Prince Edward Island, Canada. Can J Fish Aquat Sci 46:1203-1215

Bates SS, de Freitas ASW, Milley JE, Pocklington R, Quilliam MA, Smith JC, Worms J (1991) Controls on domoic acid production by the diatom Nitzschia pungens f. multiseries in culture: nutrients and irradiance. Can J Fish Aquat Sci 48:1136-1144

Blanco J, Campos MJ (1988) The effect of water conditioned by a PSP-producing dinoflagellate on the growth of four 
algal species used as food for invertebrates. Aquaculture 68:289-298

Cembella AD (2003) Chemical ecology of eukaryotic microalgae in marine ecosystems. Phycologia 42:420-447

Dahl E, Lindahl O, Paasche E, Trondsen J (1989) The Chrysochromulina polylepis bloom in Scandinavian waters during spring 1988. In: Cosper EM, Bricelj VM, Carpenter EJ (eds) Novel phytoplankton blooms. Springer-Verlag, Berlin, p 383-405

D'Elia CF, Guillard RRL, Nelson DM (1979) Growth and competition of the marine diatoms Phaedactylum tricornutum and Thalassiosira pseudonana. I. Nutrient effects. Mar Biol 50:305-312

Dickey RW, Bobzin SC, Faulkner DJ, Bencsath FA, Andrzejewski D (1990) Identification of okadaic acid from a Carribean dinoflagellate, Prorocentrum concavum. Toxicon 28:371-377

Dortch Q, Robichaux R, Pool S, Milsted D and 6 others (1997) Abundance and vertical flux of Pseudo-nitzschia in the northern Gulf of Mexico. Mar Ecol Prog Ser 146:249-264

Dutz J (1998) Repression of fecundity in the neritic copepod Acartia clausi exposed to the toxic dinoflagellate Alexandrium lusitanicum: relationship between feeding and egg production. Mar Ecol Prog Ser 175:97-107

Fistarol GO, Legrand C, Granéli E (2003) Allelopathic effect of Prymnesium parvum on a natural plankton community. Mar Ecol Prog Ser 255:155-125

Freeberg LR, Marshall A, Heyl M (1979) Interrelationships of Gymnodinium breve (Florida red tide) within the phytoplankton community. In: Taylor DL, Seliger HH (eds) Toxic dinoflagellate blooms. Elsevier-North Holland, New York, p 139-144

Fryxell GA, Villac MC, Shapiro LP (1997) The occurrence of the toxic diatom genus Pseudo-nitzschia (Bacillariophyceae) on the West Coast of the USA, 1920-1996: a review. Phycologia 36:419-437

Gallacher S, Howard G, Hess P, MacDonald E and 6 others (2001) The occurrence of amnesic shellfish poisons in shellfish from Scottish waters. In: Hallegraeff GM, Blackburn SI, Bolch CJ, and Lewis RJ (eds) Harmful Algal Blooms 2000. Intergovernmental Oceanographic Commission of UNESCO, Paris, p 30-33

Gentien P, Arzul G (1990) Exotoxin production by Gyrodinium cf. aureolum (Dinophyceae). J Mar Biol AssOC 70: $571-581$

Goldman JC, Dennett, MR, Riley CB (1981) Test for allelopathic interactions between two marine microalgal species grown in intensive cultures. Curr Microbiol 6:275-279

Goldman JC, Riley CB, Dennett, MR (1982) The effect of pH in intensive microalgal cultures. II. Species competition. J Exp Mar Biol Ecol 57:15-24

Granéli E, Johansson N (2003) Increase in the production of allelopathic substances by Prymnesium parvum cells grown under N- or P-deficient conditions. Harmful Algae 2:135-145

Gross EM (2003) Allelopathy of aquatic autotrophs. Crit Rev Plant Sci 22:313-339

Guillard RRL, Hargraves PE (1993) Stichochrysis immobilis is a diatom, not a chrysophyte. Phycologia 32:234-236

Hansen PJ (1989) red tide dinoflagellate Alexandrium tamarense: effects on behaviour and growth of a tintinnid ciliate. Mar Ecol Prog Ser 53:105-116

Hansen PJ (2002) Effect of high pH on the growth and survival of marine phytoplankton: implications for species succession. Aquat Microb Ecol 28:279-288

Hansen PJ, Hjort M (2002) Growth and grazing responses of the prymnesiophyte Chrysochromulina ericina: the role of irradiance, prey concentration and pH. Mar Biol 141: 975-983

Hasle GR (2002) Are most of the domoic acid producing species of the diatom genus Pseudo-nitzschia cosmopolites? Harmful Algae 1:137-146

Hinga KR (1992) Co-occurrence of dinoflagellate blooms and high $\mathrm{pH}$ in marine enclosures. Mar Ecol Prog Ser 86: 181-187

Hinga KR (2002) Effects of pH on coastal marine phytoplankton. Mar Ecol Prog Ser 238:281-300

Huntley M, Sykes P, Rohan S, Marin V (1986) Chemicallymediated rejection of dinoflagellate prey by the copepods Calanus pacificus and Paracalanus parvus: mechanism, occurrence and significance. Mar Ecol Prog Ser 28: $105-120$

Kotaki Y, Koike K, Yoshida M, Thuoc CV, Huyen NTM, Hoi NC, Fukuyo Y, Kodama M (2000) Domoic acid production in Nitzschia sp. (Bacillariophyceae) isolated from a shrimpculture pond in Do Son, Vietnam. J Phycol 36:1057-1060

Kotaki Y, Lundholm N, Onodera H, Kobayashi K and 5 others (2004) Wide distribution of Nitzschia navis-varingica, a new domoic acid producing benthic diatom found in Vietnam. Fish Sci 70:28-32

Landsberg JH (2002) The effect of harmful algal blooms on aquatic organisms. Rev Fish Sci 10:113-390

Lundholm N, Skov J, Pocklington R, Moestrup Ø (1994) Domoic acid, the toxic amino acid responsible for amnesic shellfish poisoning, now in Pseudonitzschia seriata (Bacillariophyceae) in Europe. Phycologia 33:475-478

Lundholm N, Hansen PJ, Kotaki Y (2004) Effect of pH on growth and domoic acid production by potentially toxic diatoms of the genera Pseudo-nitzschia and Nitzschia. Mar Ecol Prog Ser 273:1-15

Macedo MF, Duarte P, Mendes P, Ferreira JG (2001) Annual variation of environmental variables, phytoplankton species composition and photosynthetic parameters in a coastal lagoon. J PlankTON Res 23:719-723

Maldonado MT, Hughes MP, Rue EL (2002) The effect of Fe and $\mathrm{Cu}$ on growth and domoic acid production by Pseudonitzschia multiseries and Pseudo-nitzschia australis. Limnol Oceanogr 47:515-526

Maranda L, Wang R, Masuda K, Shimizu Y (1990) Investigation of the source of domoic acid in mussels. In: Granéli E, Sundström B, Edler L, Anderson DM (eds) Toxic marine phytoplankton. Elsevier, New York, p 300-304

Martin JL, Haya K, Burridge LE, Wildish DJ (1990) Nitzschia pseudodelicatissima - a source of domoic acid in the Bay of Fundy, eastern Canada. Mar Ecol Prog Ser 67:177-182

McGinness KL, Fryxell GA, McEachran JD (1995) Pseudonitzschia species found in digestive tracts of northern anchovies (Engraulis mordax). Can J Zool 73:642-647

Myklestad SM, Ramlo B, Hestmann S (1995) Demonstration of strong interaction between the flagellate Chrysochromulina polylepis (Prymnesiophyceae) and a marine diatom. In: Lassus P, Arzul G, Erard E, Gentien P, Marcaillou C (eds) Harmful marine algal blooms. Lavoisier-Intercept, Paris, p 633-638

Nielsen TG, Kiørboe T, Bjørnsen PK (1990) Effects of a Chrysochromulina polylepis subsurface bloom on the planktonic community. Mar Ecol Prog Ser 62:21-35

Pocklington R, Milley JE, Bates SS, Bird CJ, de Freitas ASW, Quilliam MA (1990) Trace determination of domoic acid in seawater and phytoplankton by high-performance liquid chromatography of the fluorenylmethoxycarbonyl (FMOC) derivative. Intern $\mathrm{J}$ Environ Anal Chem 38: 351-368

Quilliam MA, Sim PG, McCulloch AW, McInnes AG (1989) 
High-performance liquid chromatography of domoic acid, a marine neurotoxin, with application to shellfish and plankton. Intern J Environ Anal Chem 36:139-154

Rausch de Trauenberg C, Morlaix M (1995) Evidence of ocadaic acid released into extracellular medium in cultures of Prorocentrum lima (Ehrenberg) Dodge. In: Lassus P, Arzul G, Erard E, Gentien P, Marcaillou C (eds) Harmful marine algal blooms. Lavoisier-Intercept, Paris, p 493-498

Schmidt LE, Hansen PJ (2001) Allelopathy in the prymnesiophyte Chrysochromulina polylepis: effect of cell concentration, growth phase and pH. Mar Ecol Prog Ser 216: 67-81

Scholin CA, Gulland F, Doucette GJ, Benson S and 22 others (2000) Mortality of sea lions along the central California coast linked to a toxic diatom bloom. Nature 403:80-84

Sharp JH, Underhill PA, Hughes DJ (1979) Interaction (allelopathy) between marine diatoms: Thalassiosira pseudonana and Phaeodactylum tricornutum. J Phycol 15:353-362

Stonik IV, Orlova TY, Shevchenko OG (2001) Morphology and ecology of the species of the genus Pseudo-nitzschia (Bacillariophyta) from Peter the Great Bay, Sea of Japan. Russ J Mar Biol 27:362-366

Subba Rao DV, Quilliam MA, Pocklington R (1988) Domoic acid - a neurotoxic amino acid produced by the marine diatom Nitzschia pungens in culture. Can J Fish Aquat Sci 45:2076-2079

Subba Rao DV, Pan Y, Smith SJ (1995) Allelopathy between Rhizosolenia alata (Brightwell) and the toxigenic Pseudonitzschia pungens f. multiseries (Hasle). In: Lassus $\mathrm{P}$, Arzul G, Erard E, Gentien P, Marcaillou C (eds) Harmful marine algal blooms. Lavoisier Intercept, Paris, p 681-686

Sugg LM, Van Dolah FM (1999) No evidence for an allelopathic role of okadaic acid among ciguatera-associated dinoflagellates. J Phycol 35:93-103

Editorial responsibility: Otto Kinne (Editor-in-Chief), Oldendorf/Luhe, Germany
Teegarden GJ (1999) Copepod grazing selection and particle discrimination on the basis of PSP toxin content. Mar Ecol Prog Ser 181:163-176

Teegarden GJ, Cembella AD (1996) Grazing of toxic dinoflagellates, Alexandrium sp., by adult copepods of coastal Maine: implications for the fate of paralytic shellfish toxins in marine food webs. J Exp Mar Biol Ecol 196:145-176

Tillmann U, John U (2002) Toxic effects of Alexandrium spp. On heterotrophic dinoflagellates: an allelochemical defence mechanism independent of PSP-toxin content Mar Ecol Prog Ser 230:47-58

Turriff N, Runge JA, Cembella AD (1995) Toxin accumulation and feeding behaviour of the planktonic copepod Calanus finmarchicus exposed to the red-tide dinoflagellate Alexandrium excavatum. Mar Biol 123:55-64

Uchida T (1977) Excretion of a diatom-inhibitory substance by Prorocentrum micans Ehrenberg. Jpn J Ecol 27:1-4

Utermöhl H (1958) Zur Vervollkommnung der quantitativen Phytoplanktonmethodik. Mitt Int Ver Limnol 9:38S

Walz PM, Garrison DL, Graham WM, Cattey MA, Tjeerdema RS, Silver MW (1994) Domoic acid-producing diatom blooms in Monterey Bay, California: 1991-1993. Nat Toxins 2:271-279

Windust AJ (1992) The response of bacteria, microalgae and zooplankton to the diatom Nitzschia pungens forma multiseries, and its toxic metabolite domoic acid. MSc thesis, Dalhousie University, Halifax, Nova Scotia

Windust AJ, Wright JLC, McLachlan JL (1996) The effects of the diarrhetic shellfish poisoning toxins, okadaic acid and dinophysistoxin-1, on the growth of microalgae. Mar Biol 126:19-25

Work TM, Beale AM, Fritz L, Quilliam MA, Silver M, Buck K, Wright JLC (1993) Domoic acid intoxication of brown pelicans and cormorants in Santa Cruz, California. In: Smayda TJ, Shimizu Y (eds) Toxic phytoplankton blooms in the sea. Elsevier Sci Publ BV, Amsterdam, p 643-650

Submitted: April 19, 2004; Accepted: September 21, 2004 Proofs received from author(s): February 2, 2005 